considerations to be incorporated, as there are also in the many projects for storing water or regulating river-flow by impoundments. Such opportunities should be obvious to qualified ecologists and should never be neglected.

8) There is need for much more volume and freedom-offlow of information than is commonly available about projects for improvement of rivers and streams before decisions are made to proceed with management activities such as straightening or impoundment.

9) There has been insufficient work on follow-up activities to monitor the results - both successes and failures - of projects for conservation of rivers and streams of all types and sizes.

10) There is needed a hierarchical structure of responsibility for conservation of rivers - from the global concept to the regional level, thereafter from the regional to the national level, then from the national to local authorities' level, and finally to the individual land- and water-owners. At all of these and any involved intermediate levels of administration, the need of the aquatic environment itself is liable to be forgotten, or to be overridden by economic considerations or political objectives, which must be resisted whenever and wherever the long-term interest is at stake.

11) If rivers are to be conserved successfully in potential perpetuity and their resources managed constructively, the greatest possible effort must be made to involve the local public directly in the decision-making process and, wherever practicable, effective execution. For ultimate success in this the basic need will be due understanding through effective environmental education.
12) While the theme of rivers attracting populations which are growing rapidly was not debated in detail, nor its relationship to river conservation and management specifically, there was unopposed support for the expressed belief that what our unique but beleaguered Planet really needs for its salvation is control of the threat of too many people and the evolution of a new dominant cult of Mankind that will place due consideration on welfare of The Biosphere before all selfish personal, economic, national, and other, interests.

\section{E. BARTON WORTHINGTON Colin Godmans, Furners Green Near Uckfield, Sussex TN22 3RR England, UK,}

Robin L. Welcomme, Chief

Inland Water Resources \& Aquaculture Service Fishery Resources \& Environment Division Food and Agriculture Organization of the United Nations (FAO)

Via delle Terme di Caracalla 00100 Rome, Italy,

\section{$\&$}

Nicholas Polunin

Founder and Editor of Environmental Conservation

\title{
The Cambridge Columbus Botanical Study, Venezuela 1990
}

The principal centres for endemic and relict taxa in Venezuela are to be found in the Andes, the Coastal Cordillera, the Interior Coastal Range, and the Pantepui Region. This study will be based on the Peninsula de Paria, which forms the easternmost tip of the Coastal Cordillera ( $c f$. Fig. 1). It is a plant refuge that is notable for the large number of species which are common only to the Peninsula and Trinidad \& Tobago, and for harbouring relict Amazonian-Guayanan elements (Steyermark \& Agostini, 1966).

The ecostasis of the Peninsula is under threat from deforestation. The natives of the Peninsula are responsible, as they use the cleared ground to grow coffee and cocoa. The present rate of deforestation has been recognized as unsustainable by Venezuelan Conservation bodies such as Fundacion Vuelta Larga and The Columbus 500 Project, and The Cambridge Columbus Botanical Study is working closely with these organizations. The Study team comprises four graduates from the University of Cambridge, and four students from the University of Caracas. Work will be restricted to the highest peak in the area, Cerro Humo - until now largely unstudied.

The team will:

1) Compile a comprehensive plant collection from Cerro Humo, paying particular attention to the endemic and endangered species.

2) Compare that collection with similar studies of Steyermark \& Agostini (1966), Grubb \& Tanner (1976), Sugden (1982, 1986), and Milliken (1984).

3) Study the effects of deforestation around Cerro Humo on the flora of the region.

Separate studies will be made of primary and secon-

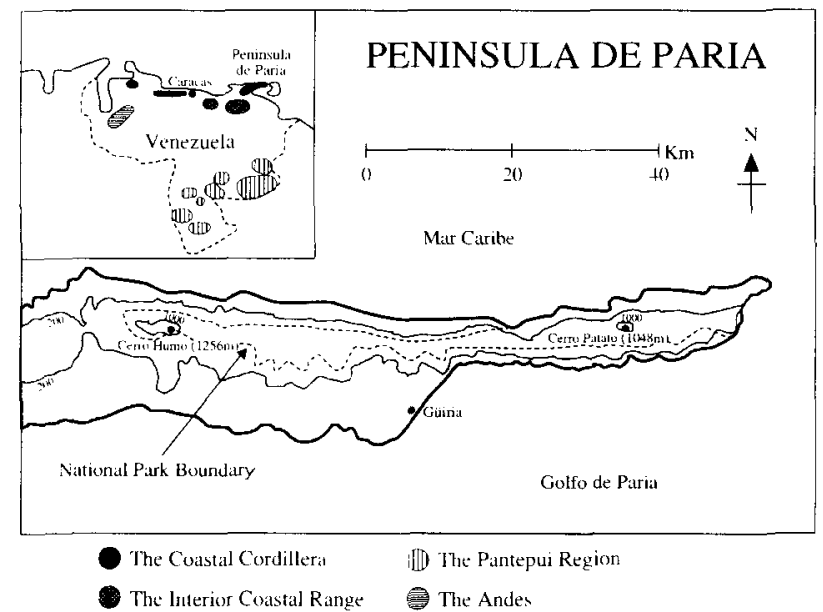

FIG. 1. Sketch-map of the Peninsula de Paria, on the Caribbean Sea coast of Venezuela (see also inset maplet).

dary forest, the degree of deforestation, and the altitudinal distribution of species across the Peninsula. This will reveal which species and which regions of the Peninsula are most threatened, and will then permit evaluation of possible conservation measures, such as the extension of the National Park's boundaries.

A preliminary report will be prepared in Caracas, which will merely give an account of the deforestation observed 
and may highlight any immediate danger to the Peninsula's ecostasis. The final report will await identification of the bulk of the specimens, and this will be carried out in England. The report will form part of a socio-economic and ecological study that is being carried out by the Columbus 500 Project, which aims to involve the native inhabitants in planning the sustainable development of the region.

The team are currently fund-raising and finalizing plans for this important project. Advice or assistance of any form would be gratefully appreciated and should be addressed to the undersigned.

\section{REFERENCES}

Grubb, P.J. \& TANneR, E.V.J. (1976). The montane forests and soils of Jamaica: a reassessment. J. Arnold Arboretum, 57, pp. 313-67.

MILLIKEN, W. (1984). Interim report of The Cambridge Botanical Expedition to Venezuela, 1984. Cambridge University
Explorers \& Travellers Club Library, Cambridge, England, UK: [not available for checking].

Steyermark, J. \& Agostini, G. (1966). Exploracion Botanica del Cerro Patao y Zonas adyacentes a Puerto Hierro, en La Peninsula de Paria, estado Sucre. Acta Botanica Venezuela, 1(2), pp. 7-80.

Sugden, A.M. (1982). The vegetation of the Serrania De Macuira, Guajira, Colombia: a contrast of arid lowlands and an isolated cloud forest. J. Arnold Arboretum, 63, pp. 1-30.

SUGDEN, A.M. (1986). The montane vegetation and flora of Margarita Island, Venezuela. J. Arnold Arboretum, 67, pp. 187-232.

\section{Air Pollution and Forest Damage in Europe: Still Critical but Some Improvements}

Air pollution continues to take a heavy toll in Europe, according to a survey of forest health in 26 states coordinated by the United Nations Economic Commission for Europe (ECE). Compared with previous years, several countries reported a further increase in forest damage during 1989 - especially in Eastern Europe - while in other countries the degree of defoliation appears to have stabilized or actually decreased.

The ECE forest damage survey - fourth in a series of annual reports undertaken since 1986 with the assistance of the United Nations Environment Programme - was carried out by an international programme task-force led by the Federal Republic of Germany, in the context of the 'Convention on Long-range Transboundary Air

TABLE I

1989 ECE Survey: Coniferous Forests - All Ages - Defoliation by Classes.**

\begin{tabular}{|c|c|c|c|c|c|c|}
\hline $\begin{array}{l}\text { Participating countries } \\
\text { etc. }\end{array}$ & $\begin{array}{c}\text { Coniferous } \\
\text { forest } \\
(1,000 \mathrm{ha})\end{array}$ & $\begin{array}{c}0 \\
\text { none } \\
(\%)\end{array}$ & $\begin{array}{c}1 \\
\text { slight } \\
(\%)\end{array}$ & $\begin{array}{c}2 \\
\text { moderate } \\
(\%)\end{array}$ & $\begin{array}{c}3+4 \\
\text { severe } \\
(\%)\end{array}$ & $\begin{array}{c}2+3+4 \\
(\%)\end{array}$ \\
\hline Austria & 2,518 & 76.0 & 19.9 & 3.3 & 0.8 & 4.1 \\
\hline Belgium (Flanders) & 54 & 35.9 & 49.1 & 13.6 & 1.4 & 15.0 \\
\hline Belgium (Wallonia) & 248 & 47.6 & 28.5 & 20.0 & 3.9 & 23.9 \\
\hline Bulgaria & 1,172 & 22.0 & 45.1 & 30.6 & 2.3 & 32.9 \\
\hline Byelorussian SSR* & 4,760 & 12.0 & 12.0 & 68.0 & 8.0 & 76.0 \\
\hline Czech \& Slovak Fed. Rep. & 2,891 & 27.0 & 41.0 & 26.0 & 6.0 & 32.0 \\
\hline Denmark & 308 & 55.0 & 21.0 & 21.0 & 3.0 & 24.0 \\
\hline Finland & 18,484 & 59.3 & 22.0 & 16.4 & 2.3 & 18.7 \\
\hline France & 4,840 & 75.4 & 17.4 & 6.7 & 0.5 & 7.2 \\
\hline Germany (East) & 2,003 & 42.8 & 39.7 & 14.8 & 2.7 & 17.5 \\
\hline Germany (West) & 5,078 & 51.5 & 35.3 & 12.3 & 0.9 & 13.2 \\
\hline Greece & 954 & 57.8 & 35.5 & 5.9 & 0.8 & 6.7 \\
\hline Hungary & 1,405 & 64.3 & 22.4 & 11.7 & 1.6 & 13.3 \\
\hline Ireland & 334 & 47.2 & 39.6 & 12.6 & 0.6 & 13.2 \\
\hline Italy & 1,735 & 77.0 & 13.8 & 7.6 & 1.6 & 9.2 \\
\hline Italy (Bolzano) & 292 & 81.6 & 14.1 & 3.8 & 0.5 & 4.3 \\
\hline Luxembourg & 31 & 74.9 & 15.6 & 7.7 & 1.8 & 9.5 \\
\hline Netherlands & 208 & 53.2 & 29.1 & 15.5 & 2.2 & 17.7 \\
\hline Norway & 5,925 & 57.0 & 28.2 & 12.5 & 2.3 & 14.8 \\
\hline Poland & 6,895 & 17.8 & 47.7 & 32.8 & 1.7 & 34.5 \\
\hline Portugal & 1,315 & 83.5 & 6.7 & 4.9 & 4.9 & 9.8 \\
\hline Spain & 5,637 & 78.7 & 17.8 & 3.1 & 0.4 & 3.5 \\
\hline Sweden & 19,400 & 51.9 & 35.2 & 11.3 & 1.6 & 12.9 \\
\hline Switzerland & 777 & 53.0 & 33.0 & 11.0 & 3.0 & 14.0 \\
\hline Ukrainian SSR* & 4,159 & 83.5 & 15.1 & 1.4 & 0.0 & 1.4 \\
\hline USSR (Estonia) & 1,153 & 38.8 & 32.7 & 27.8 & 0.7 & 28.5 \\
\hline USSR (Kaliningrad) & 123 & 11.0 & 46.0 & 41.0 & 2.0 & 43.0 \\
\hline USSR (Lithuania) & 1,008 & 32.0 & 44.0 & 22.0 & 2.0 & 24.0 \\
\hline United Kingdom & 1,550 & 36.0 & 30.0 & 25.0 & 9.0 & 34.0 \\
\hline Yugoslavia (Slovenia) & 1,210 & 33.6 & 27.3 & 22.9 & 16.3 & 39.1 \\
\hline
\end{tabular}

* Selective regional surveys.

** Defoliation classes (percentage of needles lost): $0=<10 \% ; 1=10-25 \% ; 2=25-60 \% ; 3=>60 \% ; 4=$ dead trees. 